\title{
MODEL PEMBELAJARAN GERAK DASAR BERBASIS PERMAINAN OLAHRAGA TRADISIONAL PADA ANAK USIA 10-12 TAHUN
}

\author{
Abdul Hakim Siregar, Fajar Sidik Siregar
}

Surel: abdhakim@unimed.ac.id

\begin{abstract}
The purpose of this research is to produce a product and to test the effectiveness of the basic motion learning model based on traditionalsports games for children aged 10-12 years. This research and development method uses Research and Development $(R \& D)$ which adopts the theory of Borg \& Gall by using 10 stages of development. Collecting data using observation, questionnaires, interviews and tests. The data analysis technique used descriptive qualitative and quantitative. The research sample consisted of 60 children aged 10-12 years which were divided into 30 children in the experimental group and 30 children in the controlgroup. The basic movement learning model based on traditional sports games canbe received effectively given to children aged 10-12 years based on expert validation, field tests (small group trials and large group trials) and the results of learning basic movements in the experimental group using traditional sports game models are more effective than the control group using the conventional model in children aged 10-12 years based on the effectiveness test.
\end{abstract}

Keywords: Basic Movement, Learning Outcomes, TraditionalSports Games

\begin{abstract}
ABSTRAK
Tujuan penelitian menghasilkan produk dan menguji efektifitas model pembelajaran gerak dasar berbasis permainan olahraga tradisional pada anak usia 10-12 tahun. Metode penelitian dan pengembangan ini menggunakan Research and Development (R\&D) yang mengadopsi teori Borg \& Gall dengan menggunakan 10 langka tahapan pengembangan. Pengumpulan data menggunakan observasi, angket, wawancara dan test. Teknik analisi data menggunakan deskriptif kualitatif dan kuantitatif. Sampel penelitian berjumlah 60 anak usia 10-12 tahun yang terbagi menjadi 30 anak kelompok eksperimen dan 30 anak kelompok Kontrol. model pembelajaran gerak dasar berbasis permainan olahraga tradisional dapat diterima secara efektif diberikan pada anak usia 10-12 tahun berdasarkan validasi ahli, uji lapangan (ujicoba kelompok kecil dan ujicoba kelompok besar) dan hasil belajar gerak dasar atas kelompok eksperimen menggunakan model permainan olahraga tradisional lebih efektif dari pada kelompok kontrol yang menggunakan model konvensional pada anak usia 10-12 tahun berdasarkan uji efektivitas.
\end{abstract}

Kata Kunci: Gerak Dasar, Hasil Belajar, Permainan Olahraga Tradisional

\section{PENDAHULUAN}

Pendidikan di sekolah dasar merupakan lembaga yang dikelola dan diatur oleh pemerintah berlangsung selama 6 tahun. Tujuan Pendidikan Dasar yang tidak lain agar anak indonesia menjadi seorang individu yang telah diamanatkan atau yang 
sudah dicita-citakan dalam UndangUndang Dasar 1945. Standar Kompetesi Lulusan (SKL) Pendikan Dasar sendiri adalah meletakkan dasar kecerdasan, pengetahuan, kepribadian, akhlak mulia serta keterampilan untuk hidup mandiri dan mengikuti pendidikan lebih lanjut. Mata pelajaran SD berdasarkan strukttur kurikulum 2013 terdiri atas mata pelajaran umum kelompok A dan mata pelajaran umum kelompok $\mathrm{B}$. Mata pelajaran kelompok A merupakan program kurikuler yang bertujuan untuk mengembangkan kompetensi sikap, kompetensi pengetahuan, dan kompetensi keterampilan peserta didik sebagai dasar penguatan kemampuan dalam kehidupan bermasyarakat, berbangsa dan bernegara. Mata pelajaran yang mencakup kelompok A adalah Pendidikan Agama dan Budi Pekerti, Pendidikan Pancasila dan Kewarganegaraan, Bahasa Indonesia, Matematika, Ilmu Pengetahuan Alam dan Ilmu Pengetahuan Sosial. Mata pelajaran umum kelompok B merupakan program kurikuler yang bertujuan untuk mengembangkan kopetensi sikap, kompetensi pengetahuan, dan kopetensi keterampilan peserta didik terkait lingkungan dalam bidang sosial, budaya dan seni. Mata pelajaran untuk kelompok meliputi Seni Budaya dan Prakarya dan Pendidikan Jasmani, Olahraga, dan Kesehatan. Pada pengembangan materi mata pelajaran kelompok A yang merupakan kelompok mata pelajaran yang muatan dan acuannya dikembangkan oleh pusat. Sedangkan, untuk mata pelajaran kelompok B merupakan kelompok mata pelajaran yang muatan dan acuannya dikembangkan oleh pusat dan dapat dilengkapi dengan muatan/konten local. Berdasarkan pemaparan di atas, peneliti memfokuskan penelitian khusus pada mata pelajaran Pendidikan Jasmani, Olahraga, dan Kesehatan sesuai dengan bidang peneliti.

Pendidikan jasmani, olahraga dan kesehatan merupakan salah satu mata pelajaran yang ada di Sekolah Dasar. Sekolah Dasar merupakan lembaga pendidikan formal dasar yang mempersiapkan setiap peserta didiknya agar dapat menempuh atau mengikuti jenjang pendidikan formal yang lebih tinggi. Pendidikan formal yang dimaksud adalah pendidikan yang dilaksanakan berdasarkan kurikulum tingkat satuan pendidikan pada masing-masing mata pelajaran, yang mana pada masing-masing mata pelajaran terdapat standar isi yang memuat kompetensi inti dan kompetensi dasar atau yang lebih dipahami sebagai tujuan pembelajaran umum dan tujuan pembelajaran khusus yang akan dicapai melalui proses pembelajaran dalam kelas.

Pelaksanaan pendidikan jasmani, olahraga dan kesehatan berbeda dan lebih unik dari bentuk pendidikan lainnya, karena pembelajarannya dilaksanakan melalui aktivitas jasmani. Namun dalam hal ini, masih banyak pihak yang salah kaprah tentang pendidikan jasmani. Dikarenakan pendidikan ini menggunakan gerak atau aktivitas 


\section{SCHOOL EDUCATION JOURNAL VOLUME 11 NO. 4 DESEMBER 2021}

jasmani sebagai sarana pembelajaran, maka dianggap pendidikan ini hanyalah sebagai pelengkap karena diperuntukan bagi jasmani saja, sedangkan jelas bahwa siswa adalah manusia yang tidak terdiri dari bagianbagian yang terpilah-pilah, namun merupakan kesatuan berbagai bagian yang terpadu, sehingga pelaksanaan pendidikan jasmani, olahraga dan kesehatan adalah untuk siswa sebagai manusia seutuhnya dalam mencapai tujuan pendidikan.

Proses pembelajaran pendidikan jasmani, olahraga dan kesehatan, guru memegang peranan dalam terlaksananya proses pembelajaran. Guru harus memperhatikan banyak hal berkenaan dengan siswa dalam pembelajaran pendidikan jasmani, olahraga dan kesehatan seperti aspek pertumbuhan dan perkembangan anak, dan karakteristik psikologi anak. Sebagaimana yang diuraikan dalam Kurikulum 2013 bahwa pendidikan jasmani, olahraga dan kesehatan merupakan media untuk mendorong pertumbuhan fisik, perkembangan psikis, keterampilan motorik, pengetahuan dan penalaran, penghayatan nilai-nilai (sikap-mentalemosional-sportivitas-spritual-sosial), serta pembiasaan pola hidup sehat yang bermuara untuk merangsang pertumbuhan dan perkembangan kualitas fisik dan psikis yang seimbang. Oleh sebab itu, materi pelajaran, metode pembelajaran, sarana dan prasarana yang digunakan serta alat evaluasi harus disesuaikan dengan tahap perkembangan, karakteristik dan kebutuhan anak, dengan cara demikian tujuan pembelajaran dapat tercapai secara optimal.

Lembaga

pendidikan merupakan wadah yang secara terencana dipercaya dapat menyiapkan peserta didik yang memiliki karakter dengan usaha seluruh komponen mengembangkan potensi yang dimiliki peserta didik. Karakter yang diharapkan dimiliki peserta didik sebagaimana yang diungkapkan dalam buku pelatihan dan pengembangan pendidikan budaya karakter bangsa yang diterbitkan oleh Kementerian Pendidikan ada delapan belas karakter yaitu religius, jujur, toleran, disiplin, kerja keras, kreatif, mandiri, demokratis, rasa ingin tahu, semangat kebangsaan, cinta tanah air, menghargai prestasi, bersahabat/komunikatif, cinta damai, gemar membaca, peduli lingkungan, peduli sosial dan tanggung jawab. Dalam hal menanamkan nilai karakter pada Sekolah Dasar dibutuhkan inovasi baru yang dimuat dalam perangkat pembelajaran mulai dari RPP, Bahan Ajar, Media, LKPD dan Evaluasi pada setiap mata pelajaran, khusus penelitian ini akan difokuskan pada mata pelajaran Pendidikan Jasmani, Olahraga dan Kesehatan.

\section{METODE PENELITIAN}

Penelitian dan pengembangan ini menggunakan pendekatan kualitatif dan kuantitatif, yang digunakan untuk mendeskripsikan dan menjelaskan data-data dalam bentuk angka, terutama digunakan ketika 


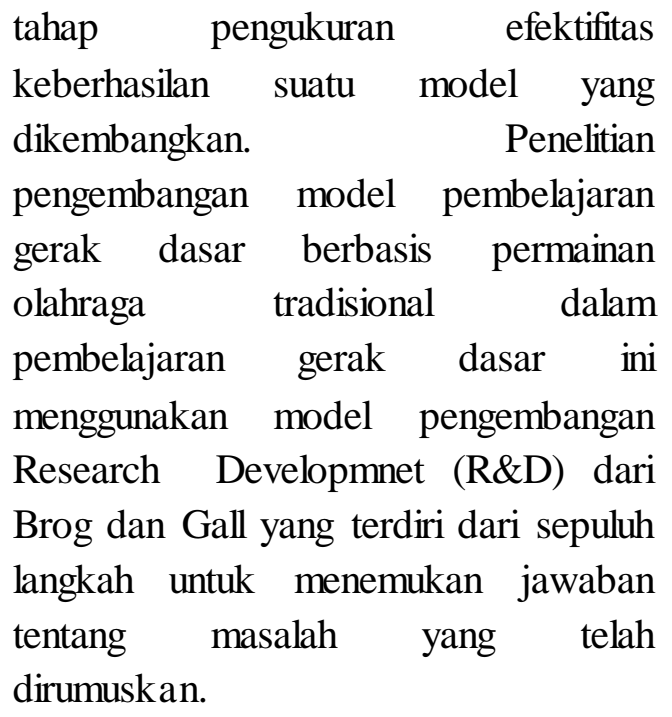

Secara umum, alur penelitian dan pengembangan model Research and Devlopment dari gambar diatas sebagai berikut:
1. Penelitian Pendahuluan dan pengumpulan Informasi (studi pendahuluan)

2. Melakukan penelitian dan pengumpulan informasi (kajian pustaka, pengamatan subyek, persiapan laporan pokok persoalan)

3. Mengembangkan bentuk desain produk awal (penyiapan materi pengajaran, penyusunan buku pegangan, dan perlengkapan evaluasi)

4. Validasi desain (evaluasi tahap awal)

5. Uji Coba Produk (6-12 subjek)

6. Melakukan revisi produk (berdasarkan saran-saran sesuai dengan hasil di lapangan pada tahap uji coba)

7. Uji coba pemakaian dengan $30-100$ subjek

8. Melakukan revisi produk (berdasarkan saran-saran dan hasil uji coba lapangan utama
9. Uji Efektifitas

10. Revisi produk akhir

11. Produksi massal (Membuat laporan mengenai produk pada jurnal, bekerja dengan penerbit yang dapat melakukan distribusi secara komersial/desiminasi) (Borg \& Gall, 1983).

Tempat pelaksanaan penelitian adalah kota Medan yang terletak di Sumatera Utara. Kota Medan adalah ibu kota provinsi Sumatra Utara, Indonesia. Kota ini merupakan kota terbesar ketiga di Indonesia. Pada penelitian ini 5 (lima) Sekolah Dasar (SD) yang menjadi tempat subjek penelitian terhadap model pembelajaran gerak dasar berbasis permainan olahraga tradisional pada anak usia 10-12 tahun.

\section{HASIL PENELITIAN DAN PEMBAHASAN}

Hasil pengembangan model dalam penelitian ini adalah berupa buku model pembelajaran gerak dasar berbasis permainan olahraga tradisional pada anak usia 10-12 tahun yang menarik, menyenangkan dan variatif serta mudah untuk dilaksanakan. Berdasarkan pelaksanaan kegiatan penelitian yang sudah dilakukan oleh peneliti dilapangan, diperoleh data hasil hasil (1) Analisis kebutuhan atau penelitian pendahuluan yang memuat hasil observasi, wawancara, angket dan studi literatur, (2) Perencanaan pengembangan variasi yang memuat tentang desain produk, (3) Validasi desain dengan menggunakan telaah pakar atau uji ahli, (4) Revisi produk 
berdasarkan hasil telaah pakar, (5)

Ujicoba pada kelompok kecil, (6) Revisi produk berdasarkan kegiatan uji coba kelompok kecil, (7) Uji coba produk pada kelompok besar, (8) Revisi produk,(9) Hasil uji efektivitas produk dan (10) Diseminasi hasil penelitian. Pada metode pengumpulan data berupa instrumen yang diberikan kepada: (1) dua orang guru berupa lembar wawancara, (2) melakukan analisis kebutuhan dengan angket yang diberikan kepada 20 orang subjek penelitian, (3) instrumen mengenai kelayakan produk yang diberikan kepada ahli terhadap desain produk pengembangan yang dilakukan, adapun ahli/pakar/ilmuan terdiri: (a) ahli pembelajaran pendidikan jasmani, olahraga dan kesehatan (b) ahli Permainan olahraga tradisional, (c) ahli desain media pembelajaran. (d) Ahli Instrument PJOK, (4) Uji coba kelompok kecil sebanyak 30 subjek penelitian, (5) uji coba kelompok besar sebanyak 120 subjek penelitian, (6) uji efektivitas produk sebanyak 60 subjek terdiri dari 30 subjek kelompok eksprimen dan 30 subjek kontrol.

Setelah melakukan uji coba kelompok kecil dan uji kelompok besar, maka langkah selanjutnya adalah untuk mengetahui efektivitas dari produk pengembangan model pembelajaran gerak dasar berbasis permaianan olahraga tradisional. Pengolahan data untuk menguji efektivitas model pembelajaran gerak dasar berbasis permainan olahraga tradisional menggunakan prosedur ujit dengan dibantu softwere IBM SPSS 25. Sebelum melakukan analisis data, maka data diperoleh harus memenuhi salah satu uji prasyarat analisis yakni uji normalitas untuk data kelas eksprimen dan kelas kontrol pada keterampilan gerak dasar dengan menggunakan uji KolmogorovSmirnov pada taraf signifikan $\alpha=0,05$. Berikut ini merupakan hasil uji pada kelompok eksperimen dan kelompok kontrol:

Tabel 1. Deskriptif Statistik Hasil Pretest \&Posttest Kelompok Eksperimen

\begin{tabular}{ccccc}
\hline $\begin{array}{c}\text { Kelompok } \\
\text { Eksperimen }\end{array}$ & Mean & N & $\begin{array}{c}\text { Std. } \\
\text { Deviation }\end{array}$ & Std. Error Mean \\
\end{tabular}

\begin{tabular}{rrrrr}
\hline Pre-test & 164,10 & 30 & 3,367 & 0,615 \\
\hline Post-test & 172,73 & 30 & 5,558 & 1,015 \\
\hline
\end{tabular}

Pada tabel 1, rata-rata hasil tes keterampilan gerak dasar dengan sampel 30 siswa diperoleh pretest memiliki mean sebesar 164,10 dan standar deviasi sebesar 3,36. Setelah diberikan treatment model pembelajaran gerak dasar berbasis permainan olahraga tradisional maka hasil post test memiliki mean sebesar 172,73 dan standar deviasi sebesar 5,55 . 
Tabel 2. Uji Paired Samples Statistics Pretest \& Posttest Kelompok Kontrol

\begin{tabular}{ccccc}
\hline $\begin{array}{c}\text { Kelompok } \\
\text { Kontrol }\end{array}$ & Mean & N & $\begin{array}{c}\text { Std. } \\
\text { Deviation }\end{array}$ & Std. Error Mean \\
\hline Pre-test & 141,03 & 30 & 11,038 & 2,015 \\
\hline Post-test & 145,37 & 30 & 6,278 & 1,146 \\
\hline
\end{tabular}

Berdasarkan tabel 4, dengan jumlah sampel 30 orang diperoleh hasil mean pre test sebesar 141,03 dan standar deviasi sebesar 11,038. Setelah diberikan model pembelajaran gerak dasar konvensional maka hasil mean post test sebesar 145,37 dan standar deviasi sebesar 6,278. Hal ini berarti secara kuantitatif pada tabel 3 terlihat ada perbedaan hasil pre test dan post test sebelum dan sesudah diberikan treatment dengan menggunakan model konvesional. Untuk mengetahui korelasi hasil pre test dan post test pada kelompok kontrol dilakukan uji paired samples correlation sebagai berikut:

Tabel 3. Rangkuman Hasil Perhitungan Uji Normalitas Data Kelompok Eksperimen Dan Kelompok Kontrol Pada Kete rampilan Ge rak Dasar

\begin{tabular}{|c|c|c|c|c|c|c|c|}
\hline \multicolumn{8}{|c|}{ Tests of Normality } \\
\hline & \multirow[b]{2}{*}{ Kelompok } & \multicolumn{3}{|c|}{ Kolmogorov-Smirnov $^{\mathrm{a}}$} & \multicolumn{3}{|c|}{ Shapiro-Wilk } \\
\hline & & Statistic & $\mathrm{df}$ & Sig. & Statistic & $\mathrm{df}$ & Sig. \\
\hline Hasil & Kelompok & 0,157 & 30 & 0,058 & 949 & 30 & 0,157 \\
\hline Belajar & Eksperimen & & & & & & \\
\hline Gerak & Kelompok & 0,148 & 30 & 0,092 & ,932 & 30 & 0,055 \\
\hline Dasar & Kontrol & & & & & & \\
\hline
\end{tabular}

Berdasarkan tabel 3, hasil pengujian dapat dilihat pada kolom Kolmogorov-Smirnov, diketahui bahwa nilai sig untuk data kelompok eksperimen sebesar 0,058 dan data kelompok kontrol sebesar 0,092. Hasil nilai sig kedua kelompok $>\alpha(0,05)$ maka dapat disimpulkan bahwa keseluruhan data kelompok penelitian berdistribusi normal.

\section{Pembahasan}

Melalui penelitian ini menunjukkan bahwa secara umum dihasilkan hasil pengembangan model pembelajaran gerak dasar berbasis permaianan olahraga tradisional dapat dilaksanakan oleh usia anak 10-12 tahun. Sejalan dengan pendapat Model pembelajaran dapat diartikan sebagai suatu rencana atau pola yang digunakan dalam menyusun kirikulum, mengatur materi pembelajaran dan memberi petunjuk pada pengajar dalam proses pembelajaran. Elias M. Award \& Hassan M Ghaziri (2010) menyatakan bahwa "A models is a representation of real of planned system." Maksud dari pernyataan tersebut adalah model 
sebagai suatu representasi dari suatu kenyataan system yang direncanakan. Model pembelajaran merupakan sebuah rencana yang dimanfaatkan untuk merancang. Isi yang terkandung di dalam model pembelajaran adalah berupa strategi pengajaran yang digunakan untuk mencapai tujuan instruksional.Hasil pengembangan model pembelajaran gerak dasar berbasis permaianan olahraga tradisional dapat dilaksanakan oleh usia anak 10-12 tahun dalam melakukan observasi penggunaan model dan aktivitas siswa ditemukan bahwasannya proses pembelajaran olahraga semakin di senangi siswa baik dari segi kognetif, afektif dan psikomorik sejalan dengan pendapat Thomas, $\mathrm{dkk}$ (2008) mengelompokkan hasil belajar ke dalam tiga ranah, yaitu (1) ranah kognitif, (2) ranah afektif, dan (3) ranah psikomotor. Ranah kognitif merupakan penguasaan anak terhadap gerak dasar olahraga dan pengetahuan yang telah diperoleh melalui suatu proses pembelajaran yang berhubungan dengan kegiatan berpikir, mengingat, dan memecahkan masalah yang menunjuk kepada informasi yang tersimpan dalam pikiran melalui olahraga permainan tradisional. Ranah afektif mencakup hasil belajar yang berkaitan dengan sikap terhadap nilai-nilai, moral, dan norma tertentu yang sampaikan pada model yakni aspek Keberanian, percaya diri, semangat, kerja keras dan terampil. Sedangkan, ranah psikomotor berhubungan dengan keterampilan yang dimiliki untuk mengembangkan atau menciptakan sesuatu yang tampak pada kegiatan unjuk kerja siswa pada setiap langkahlangkah permainan olahraga tradisional. Berdasarkan ketiga pertimbangan tersebutlah peneliti mengembangan model pembelajaran gerak dasar berbasis permaianan olahraga tradisional dapat dilaksanakan oleh usia anak 10-12 tahun untuk mengurangi kebosanan siswa saat pembelajaran berlangsuang.

\section{SIMPULAN}

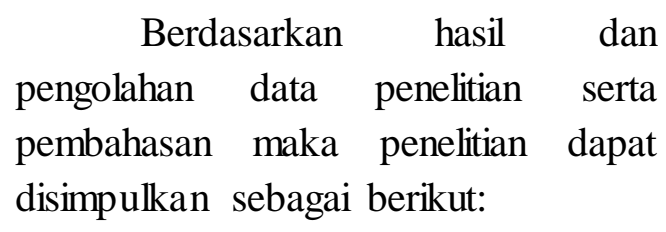

Model pembelajaran gerak dasar (lokomotor, non lokomotor dan manipulatif) berbasis permainan olahraga tradisional pada anak usia 1012 tahun dinyatakan diterima berdasarkan (a) dua ahli materi pembelajaran PJOK diperoleh hasil sebesar 78\%, (b) ahli permaianan olahraga tradisional diperoleh hasil sebesar 78\%, (c) ahli media pembelajaran diperoleh hasil sebesar $75 \%$. Secara keseluruhan rata-rata validasi penilaian produk secara keseluruhan sebesar 75\%, sehingga disimpulan model diterima. Dari hasil tersebut juga ditemukan 5 model yang tidak diterima yakni Margala A3, Bakiak C3, Marjalengkat B2, Marjalengkat C1 dan Marjalengkat C3. Total model yang diterima 49 Model dari 54 model yang dikembangkan. model pembelajaran gerak dasar (lokomotor, 
non lokomotor dan manipulatif) berbasis permainan olahraga tradisional pada anak usia 10-12 tahun efektif untuk meningkatkan hasil belajar gerak dasar. Berdasarkan hasil uji Equal variances assumed dan Levene's Test for Equality of Variances diperoleh nilai $\mathrm{F}=0,030$ dengan nilai sig atau $\mathrm{p}$-value $=0,864>$ 0.05 , yang berarti varians populasi kedua kelompok sama atau homogen. Hasil uji hipotesis Equal variances assumed dan t-test for Equality of Means diperoleh nilai $\mathrm{t}=17,877$, $\mathrm{df}=$ 58 dan sig (2 tailed) atau p-value $=0.000<0.05$ atau $\mathrm{H}_{0}$ ditolak. Hasil gerak dasar lokomotor, non lokomotor dan manipulatif berbasis permainan olahraga tradisional pada anak usia 1012 tahun atas kelompok eksperimen lebih tinggi atau efektif dari pada kelompok kontrol.

\section{DAFTAR RUJUKAN}

Borg, W. R., \& Gall, M. D. 1983. Educational Research: An Introduction, 4th Edition. In 4. Longman Inc.

Elias M. Awad, Hassan M. Ghaziri. 2010. Knowledge Management: Updated 2nd Edition English: International Technology Group, LTD

Elisa SK, Y. 2017. Efektivitas Permainan Tradisional Gobag Sodor Untuk Menurunkan Perilaku Agresif Pada Siswa Kelas II Sekolah Dasar (Vol. 549).

Thomas K.T, Lee A.M, Thomas J.R. 2008. Physical Education
Methods for Elementary

Teachers Third Edition.

Wafiqni, N. \& S. N. 2018. Model

Pembelajaran Tematik. Jurnal

Pendidikan Dasar Islam, XI(1), 119-132. 